\title{
Leptospira kmetyi sp. nov., isolated from an environmental source in Malaysia
}

\author{
Andrew T. Slack, ${ }^{1}$ Siti Khairani-Bejo, ${ }^{2}$ Meegan L. Symonds, ${ }^{1}$ \\ Michael F. Dohnt, ${ }^{1}$ Renee L. Galloway, ${ }^{3}$ Arnold G. Steigerwalt, ${ }^{3}$ \\ Abdul R. Bahaman, ${ }^{2}$ Scott Craig, ${ }^{1}$ Bruce J. Harrower ${ }^{4}$ and Lee D. Smythe ${ }^{1}$ \\ ${ }^{1}$ WHO/FAO/OIE Collaborating Centre for Reference and Research on Leptospirosis, Western \\ Pacific Region, Communicable Diseases, Queensland Health Forensic and Scientific Services, \\ Brisbane, Australia \\ ${ }^{2}$ Faculty of Veterinary Medicine, Universiti Putra Malaysia, Serdang, Selangor, Malaysia \\ ${ }^{3}$ Bacterial Zoonoses Branch, Coordinating Center for Infectious Diseases, Centers for Disease \\ Control and Prevention, Atlanta, GA, USA \\ ${ }^{4}$ Virology Department, Communicable Diseases, Queensland Health Forensic and Scientific \\ Services, Brisbane, Australia
}

Correspondence Lee D. Smythe Lee_smythe@health.qld.gov.au
A single Leptospira strain (designated Bejo-lso9 ${ }^{\top}$ ) was isolated from a soil sample taken in Johor, Malaysia. The isolate showed motility and morphology typical of the genus Leptospira under darkfield microscopy. Cells were found to be 10-13 $\mu \mathrm{m}$ in length and $0.2 \mu \mathrm{m}$ in diameter, with a wavelength of $0.5 \mu \mathrm{m}$ and an amplitude of approximately $0.2 \mu \mathrm{m}$. Phenotypically, strain BejoIso9 ${ }^{\top}$ grew in Ellinghausen-McCullough-Johnson-Harris medium at 13,30 and $37{ }^{\circ} \mathrm{C}$, and also in the presence of 8-azaguanine. Serologically, strain Bejo-Iso9 ${ }^{\top}$ produced titres towards several members of the Tarassovi serogroup, but was found to be serologically unique by cross-agglutinin absorption test and thus represented a novel serovar. The proposed name for this serovar is Malaysia. Phylogenetic analysis of $16 \mathrm{~S}$ rRNA gene sequences placed this novel strain within the radiation of the genus Leptospira, with sequence similarities within the range 90.4-99.5\% with respect to recognized Leptospira species. DNA-DNA hybridization against the three most closely related Leptospira species was used to confirm the results of the 16S rRNA gene sequence analysis. The $\mathrm{G}+\mathrm{C}$ content of the genome of strain Bejo-Iso9 ${ }^{\top}$ was $36.2 \mathrm{~mol} \%$. On the basis of phenotypic, serological and phylogenetic data, strain Bejo-lso ${ }^{\top}$ represents a novel species of the genus Leptospira, for which the name Leptospira kmetyi sp. nov. is proposed. The type strain is Bejo-Iso9 ${ }^{\top}\left(=\right.$ WHO LT1101 ${ }^{\top}=$ KIT Bejo-Iso9 $\left.{ }^{\top}\right)$.
Leptospirosis is the zoonotic disease caused by members of the genus Leptospira, helical spirochaetes that metabolize long-chain fatty acids. Leptospirosis is an emerging disease of worldwide distribution, affecting both developing and developed countries (Bharti et al., 2003; LaRocque et al., 2005; Levett, 2001; Slack et al., 2006a). The disease is transmitted by direct contact with infected animal urine or body fluids or by indirect contact with contaminated water or soil (Levett, 2001).

Abbreviations: CAAT, cross-agglutinin absorption test; EMJH, Ellinghausen-McCullough-Johnson-Harris; MAT, microscopic agglutination test.

The GenBank/EMBL/DDBJ accession numbers for the 16S rRNA, DNA gyrase subunit $B$ and RNA polymerase subunit $B$ gene sequences of Leptospira kmetyi serovar Malaysia strain Bejo-Iso9 ${ }^{\top}$ are AB279549, AB279550 and AB291211, respectively.

Supplementary tables are available with the online version of this paper.
At the time of writing, there are 18 species in the genus Leptospira, as determined by DNA-DNA hybridization (Brenner et al., 1999; Levett et al., 2006; Perolat et al., 1998; Slack et al., 2008; Yasuda et al., 1987). More recently, a further novel species, Leptospira licerasiae, has been validly published (Matthias et al., 2009). Phylogenetic analysis of the Leptospira species has resulted in their broad classification into four distinct clades: pathogenic, saprophytic, intermediate and novel (Perolat et al., 1998; Slack et al., 2008). Members of the genus Leptospira are also divided serologically through the homology of cell antigens by using the cross-agglutinin absorption test (CAAT). There have been over 200 serovars described for this genus (Levett, 2001).

In this paper, we report the characterization of a novel species of the genus Leptospira by using serology, phenotypic studies and molecular studies, including 16S 
rRNA, DNA gyrase subunit B (gyrB) and RNA polymerase subunit $\mathrm{B}(r p o B)$ gene sequence analysis, DNA-DNA hybridization and DNA G $+C$ content analysis, to define a novel species within the genus Leptospira.

Initially, strain Bejo-Iso $9^{\mathrm{T}}$ was isolated from soil in Johor, Malaysia, by researchers at the Faculty of Veterinary Medicine, Universiti Putra Malaysia, using the following isolation procedure. Soil samples $(20 \mathrm{~g}$ in sterile water at approximately three times the volume of the sample) were filtered initially through filter paper (Whatman no. 1) and then through a $0.45 \mu \mathrm{m}$ membrane filter. The filtered water was inoculated into semi-solid JS medium. The inoculated medium was incubated at $30{ }^{\circ} \mathrm{C}$ and examined weekly by using dark-field microscopy for the presence of leptospira. Strain Bejo-Iso $9^{\mathrm{T}}$ was then forwarded to the WHO/FAO/ OIE Collaborating Centre for Reference and Research on Leptospirosis, Brisbane, Australia, for further identification. Strain Bejo-Iso $9^{\mathrm{T}}$ and all other strains used in this study were maintained in Ellinghausen-McCulloughJohnson-Harris (EMJH) medium (Difco) at $30{ }^{\circ} \mathrm{C}$.

Phenotypic characterization of strain Bejo-Iso $9^{\mathrm{T}}$ was performed by assessing growth at varying temperatures and in the presence of 8-azaguanine (Johnson \& Rogers, 1964). Duplicate EMJH media were inoculated with strain Bejo-Iso $9^{\mathrm{T}}$ and incubated at 13,30 and $37{ }^{\circ} \mathrm{C}$ for 14 days. The cultures were then inspected for growth by using darkfield microscopy. Growth was confirmed by subculturing into $\mathrm{EMJH}$ medium (without 8-azaguanine) and incubating at $30{ }^{\circ} \mathrm{C}$ for a further 7 days. Leptospira interrogans serovar Pomona strain Pomona, Leptospira biflexa serovar Patoc strain Patoc $\mathrm{I}^{\mathrm{T}}$ and Leptospira inadai serovar Lyme strain $10^{\mathrm{T}}$ were used as controls in the experiments to represent pathogenic, saprophytic and intermediate species, respectively. Under dark-field microscopy, Bejo-Iso $9^{\mathrm{T}}$ showed typically leptospiral motility and morphology, and cells were found to be $10-13 \mu \mathrm{m}$ in length and $0.2 \mu \mathrm{m}$ in diameter, with a wavelength of $0.5 \mu \mathrm{m}$ and an amplitude of approximately $0.2 \mu \mathrm{m}$. Phenotypically, strain Bejo-Iso9 ${ }^{\mathrm{T}}$ grew in EMJH medium at 13,30 and $37^{\circ} \mathrm{C}$ and also in the presence of 8-azaguanine.

Serological identification of the isolate was performed by using the microscopic agglutination test (MAT) method, using serovars representative of the major Leptospira serogroups (Faine et al., 1999). Hyperimmune antiserum against strain Bejo-Iso $9^{\mathrm{T}}$ was produced in rabbits by using standard methods (Graves \& Faine, 1970). The Leptospira serogroups tested included Icterohaemorrhagiae, Javanica, Celledoni, Canicola, Ballum, Pyrogenes, Cynopteri, Autumnalis, Djasiman, Australis, Pomona, Grippotyphosa, Hebdomadis, Mini, Sejroe, Bataviae, Tarassovi, Panama, Shermani and Semaranga. CAAT was used to confirm the results from the MAT serovar-screening reactions (Kmety et al., 1970). When Bejo-Iso9 $9^{\mathrm{T}}$ was tested against hyperimmune antiserum representing the major Leptospira serogroups, it gave a significant titre to Leptospira borgpetersenii serovar Tarassovi $(1: 1600)$. Strain Bejo-Iso9 ${ }^{\mathrm{T}}$ culture and antiserum were then screened by using MAT for homology against the previously described members of the Tarassovi serogroup (the serovar MAT results are shown in Supplementary Table S1, available in IJSEM Online). It produced a significant titre against the culture and antiserum of Leptospira (undesignated species) serovar Banna strain A31. CAAT between the two isolates revealed that they were not serologically identical and, therefore, Bejo-Iso $9^{\mathrm{T}}$ represents a novel serovar, designated Malaysia. Additionally, given the initial serological reactions, it is proposed that this serovar be placed within the Tarassovi serogroup.

Cultures were prepared for DNA isolation by centrifugation as described previously (Slack et al., 2006b), followed by genomic DNA extraction using a ChargeSwitch gDNA mini bacteria kit (Invitrogen). Amplification of the 16S rRNA and gyrB genes was performed as described previously (Slack et al., 2006b, 2008). $r p o B$ gene amplification was performed by using a previously described method (La Scola et al., 2006) with the following modifications: PCR amplification was performed in $25 \mu \mathrm{l}$ volumes containing $1 \times$ PCR buffer (New England Biolabs), $1.5 \mathrm{mM} \mathrm{MgCl}, 200 \mu \mathrm{M}$ dNTPs, 10 pmol oligonucleotides [Lept 1900f (5'-CCTCATGGGTTCCAACATGCA-3') and Lept 2500r (5'-CGCATCCTCRAAGTTGTAWCCTT-3') (La Scola et al., 2006)], 1 U Taq Polymerase (New England Biolabs) and $2 \mu$ template DNA. The DNA was amplified by using the following thermal-cycling profile: $95{ }^{\circ} \mathrm{C}$ for $3 \mathrm{~min}$, followed by 30 cycles of $94{ }^{\circ} \mathrm{C}$ for $30 \mathrm{~s}, 51{ }^{\circ} \mathrm{C}$ for $30 \mathrm{~s}$ and $72{ }^{\circ} \mathrm{C}$ for $30 \mathrm{~s}$, and a final extension for $7 \mathrm{~min}$ at $72{ }^{\circ} \mathrm{C}$. DNA sequencing was performed by using BigDye Terminator sequencing, version 3.1 (Applied Biosystems), as described previously (Slack et al., 2006b, 2008). The cycle-sequencing products were purified by using sodium acetate/alcohol precipitation as per the manufacturer's instructions (Applied Biosystems) and the purified products were forwarded to the Griffith University DNA sequencing facility, Brisbane, Australia, for capillary electrophoresis using an ABI 3130xl instrument. The sequences were assembled and trimmed to a minimum of two contiguous sequences by using Vector NTI software (Invitrogen). Sequences from strain BejoIso $9^{\mathrm{T}}$ and representative $16 \mathrm{~S}$ rRNA (1331 bp), gyrB (421 bp) and rpoB (495 bp) gene sequences from members of the genus Leptospira were aligned with CLUSTAL $\mathrm{W}$ (Thompson et al., 1994). By using MEGA4 (Tamura et al., 2007), distances of aligned 16S rRNA gene sequences were estimated by the Jukes-Cantor method (Jukes \& Cantor, 1969), bootstrapped 1000 times and the tree topology was determined by the neighbour-joining method. The final phylogenetic tree was rooted by using Leptonema illini serovar Habaki strain Habaki as an outgroup and bootstrap values were displayed as percentages (Fig. 1). 16S rRNA gene sequence similarity between strain Bejo-Iso $9^{\mathrm{T}}$ and the 18 previously described species in the genus Leptospira was found to be in the range 90.4-99.5\%. Leptospira genomospecies 1 (99.5\%), Leptospira noguchii (99.2\%) and 


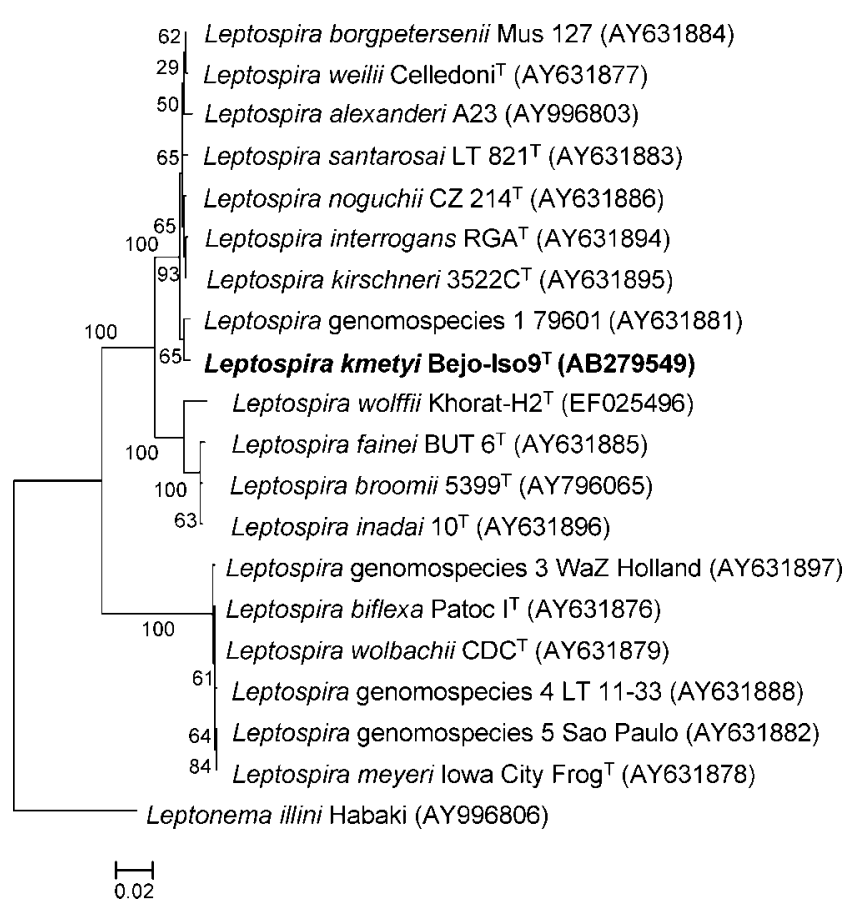

Fig. 1. $16 \mathrm{~S}$ rRNA gene sequence-based phylogeny of strain Bejo-Iso $9^{\top}$ and 18 representative species of the genus Leptospira. The dendrogram was constructed from distance matrices by using the neighbour-joining method, with Leptonema illini strain Habaki as outgroup. Bootstrap values are displayed as percentages. Bar, 0.02 inferred nucleotide substitutions per $100 \mathrm{nt}$.

Leptospira kirschneri (99.1\%) showed the highest levels of $16 \mathrm{~S}$ rRNA gene sequence similarity to strain Bejo-Iso $9^{\mathrm{T}}$. The 16S rRNA gene sequence analysis results were confirmed by gyrB (87.6-88.2\%) and rpoB (72.7-89.5\%) gene sequence analysis (shown in Supplementary Table S2, available in IJSEM Online). Phylogenetic analysis using $16 \mathrm{~S}$ rRNA gene sequences showed that strain Bejo-Iso $9^{\mathrm{T}}$ was placed within the radiation of the genus Leptospira and was found to cluster with the pathogenic Leptospira species (Fig. 1).

DNA was isolated for DNA-DNA hybridization and G + C content analysis from strain Bejo-Iso $9^{\mathrm{T}}$ and eight known pathogenic Leptospira species as described previously (Brenner et al., 1982). The DNA was labelled with $\left[{ }^{32} \mathrm{P}\right] \mathrm{dCTP}$, and DNA relatedness and divergence studies were performed by using the hydroxyapatite method at the optimal reassociation temperature of $55{ }^{\circ} \mathrm{C}$ (Brenner et al., 1982). G $+C$ content was determined by the thermaldenaturation method (Mandel et al., 1970). Strain BejoIso $9^{\mathrm{T}}$ showed no significant similarity to the previously described pathogenic Leptospira species (DNA-DNA hybridization results are shown in Supplementary Table S3, available in IJSEM Online.). The genomic G+C content of strain Bejo-Iso9 ${ }^{\mathrm{T}}$ was $36.2 \mathrm{~mol} \%$, which is within the range $33-43 \mathrm{~mol} \%$ described for the genus Leptospira (Yasuda et al., 1987).
Despite having high 16S rRNA gene sequence similarity to recognized Leptospira species, there is sufficient evidence, in the form of DNA-DNA hybridization and $r p o B$ and $g y r B$ gene sequence analysis, to justify the inclusion of strain Bejo-Iso $9^{\mathrm{T}}$ as a member of a novel species within the genus Leptospira. Interestingly, this strain has the phenotypic characteristics typical of a non-pathogenic or potentially pathogenic Leptospira species, i.e. it shows growth at $13{ }^{\circ} \mathrm{C}$ (Johnson \& Harris, 1967) and in the presence of 8azaguanine (Johnson \& Rogers, 1964), yet based upon $16 \mathrm{~S}$ rRNA gene sequence analysis, it is phylogenetically positioned amongst the pathogenic Leptospira species. Further research is required to determine whether this strain is pathogenic to humans.

This research provides sufficient evidence in the form of molecular and serological taxonomic characterization to justify the inclusion of strain Bejo-Iso $9^{\mathrm{T}}$ as the type strain of a novel species with the genus Leptospira, for which the name Leptospira kmetyi sp. nov. is proposed (serovar Malaysia). The novel species and serovar designation of strain Bejo-Iso $9^{\mathrm{T}}$ have been ratified by the International Committee on Systematic Bacteriology, Subcommittee on the Taxonomy of Leptospiraceae.

\section{Description of Leptospira kmetyi sp. nov.}

Leptospira kmetyi (kmet'yi. N.L. gen. masc. n. kmetyi after Professor Emil Kmety, a Slovak bacteriologist who made significant contributions to the study of the genus Leptospira).

Morphology and motility under dark-field microscopy are consistent with those for the genus. Cells are 10-13 $\mu \mathrm{m}$ in length and $0.2 \mu \mathrm{m}$ in diameter, with a wavelength of $0.5 \mu \mathrm{m}$ and an amplitude of approximately $0.2 \mu \mathrm{m}$. Grows at 13,30 and $37{ }^{\circ} \mathrm{C}$ and in the presence of 8 -azaguanine. Serologically, titres are produced towards several members of the Tarassovi serogroup, but serologically unique by CAAT (designated novel serovar Malaysia). Phylogenetically placed within the radiation of the genus Leptospira (based on 16S rRNA gene sequence analysis and confirmed by using DNA-DNA hybridization against the three most closely related Leptospira species). The DNA G $+\mathrm{C}$ content of the type strain is $36.2 \mathrm{~mol} \%$.

The type strain, Bejo-Iso $9^{\mathrm{T}}\left(=\mathrm{WHO}\right.$ LT1101 ${ }^{\mathrm{T}}=$ KIT BejoIso ${ }^{\mathrm{T}}$ ), was isolated from an environmental source (soil) in Johor, Malaysia.

\section{References}

Bharti, A. R., Nally, J. E., Ricaldi, J. N., Matthias, M. A., Diaz, M. M., Lovett, M. A., Levett, P. N., Gilman, R. H., Willig, M. R. \& other authors (2003). Leptospirosis: a zoonotic disease of global importance. Lancet Infect Dis 3, 757-771.

Brenner, D. J., McWhorter, A. C., Knutson, J. K. \& Steigerwalt, A. G. (1982). Escherichia vulneris: a new species of Enterobacteriaceae associated with human wounds. J Clin Microbiol 15, 1133-1140.

Brenner, D. J., Kaufmann, A. F., Sulzer, K. R., Steigerwalt, A. G., Rogers, F. C. \& Weyant, R. S. (1999). Further determination of DNA 
relatedness between serogroups and serovars in the family Leptospiraceae with a proposal for Leptospira alexanderi sp. nov. and four new Leptospira genomospecies. Int J Syst Bacteriol 49, 839-858.

Faine, S., Adler, B. \& Bolin, C. (1999). Leptospira and Leptospirosis. Melbourne, Australia: MediSci.

Graves, S. \& Faine, S. (1970). Antileptospiral agglutinins produced in rabbits. Bull World Health Organ 43, 579-587.

Johnson, R. C. \& Harris, V. G. (1967). Differentiation of pathogenic and saprophytic letospires. I. Growth at low temperatures. J Bacteriol 94, 27-31.

Johnson, R. C. \& Rogers, P. (1964). Differentiation of pathogenic and saprophytic leptospires with 8-azaguanine. J Bacteriol 88, 1618-1623.

Jukes, T. H. \& Cantor, C. R. (1969). Evolution of protein molecules. In Mammalian Protein Metabolism, pp. 21-132. Edited by H. N. Munro. New York: Academic Press.

Kmety, E., Galton, M. M. \& Sulzer, C. R. (1970). Further standardization of the agglutinin-absorption test in the serology of leptospires. Bull World Health Organ 42, 733-738.

LaRocque, R. C., Breiman, R. F., Ari, M. D., Morey, R. E., Janan, F. A., Hayes, J. M., Hossain, M. A., Brooks, W. A. \& Levett, P. N. (2005). Leptospirosis during dengue outbreak, Bangladesh. Emerg Infect Dis 11, 766-769.

La Scola, B., Bui, L. T., Baranton, G., Khamis, A. \& Raoult, D. (2006). Partial $r p o B$ gene sequencing for identification of Leptospira species. FEMS Microbiol Lett 263, 142-147.

Levett, P. N. (2001). Leptospirosis. Clin Microbiol Rev 14, 296-326.

Levett, P. N., Morey, R. E., Galloway, R. L. \& Steigerwalt, A. G. (2006). Leptospira broomii sp. nov., isolated from humans with leptospirosis. Int J Syst Evol Microbiol 56, 671-673.

Mandel, M., Igambi, L., Bergendahl, J., Dodson, M. L., Jr \& Scheltgen, E. (1970). Correlation of melting temperature and cesium chloride buoyant density of bacterial deoxyribonucleic acid. J Bacteriol 101, 333-338.
Matthias, M. A., Ricaldi, J. N., Cespedes, M., Diaz, M. M., Galloway, R. L., Saito, M., Steigerwalt, A. G., Patra, K. P., Ore, C. V. \& other authors (2009). Leptospira licerasiae sp. nov. In List of New Names and New Combinations Previously Effectively, but not Validly, Published, Validation List no. 125. Int J Syst Evol Microbiol 59, 1-2.

Perolat, P., Chappel, R. J., Adler, B., Baranton, G., Bulach, D. M., Billinghurst, M. L., Letocart, M., Merien, F. \& Serrano, M. S. (1998). Leptospira fainei sp. nov., isolated from pigs in Australia. Int J Syst Bacteriol 48, 851-858.

Slack, A. T., Symonds, M. L., Dohnt, M. F. \& Smythe, L. D. (2006a). The epidemiology of leptospirosis and the emergence of Leptospira borgpetersenii serovar Arborea in Queensland, Australia, 1998-2004. Epidemiol Infect 134, 1217-1225.

Slack, A. T., Symonds, M. L., Dohnt, M. F. \& Smythe, L. D. (2006b). Identification of pathogenic Leptospira species by conventional or real-time PCR and sequencing of the DNA gyrase subunit B encoding gene. BMC Microbiol 6, 95.

Slack, A. T., Kalambaheti, T., Symonds, M. L., Dohnt, M. F., Galloway, R. L., Steigerwalt, A. G., Chaicumpa, W., Bunyaraksyotin, G., Craig, S. \& other authors (2008). Leptospira wolffii sp. nov., isolated from a human with suspected leptospirosis in Thailand. Int J Syst Evol Microbiol 58, 2305-2308.

Tamura, K., Dudley, J., Nei, M. \& Kumar, S. (2007). MEGA4: Molecular evolutionary genetics analysis (MEGA) software version 4.0. Mol Biol Evol 24, 1596-1599.

Thompson, J. D., Higgins, D. G. \& Gibson, T. J. (1994). Clustal W: improving the sensitivity of progressive multiple sequence alignment through sequence weighting, position-specific gap penalties and weight matrix choice. Nucleic Acids Res 22, 4673-4680.

Yasuda, P. H., Steigerwalt, A. G., Sulzer, K. R., Kaufmann, A. F., Rogers, F. \& Brenner, D. J. (1987). Deoxyribonucleic acid relatedness between serogroups and serovars in the family Leptospiraceae with proposals for seven new Leptospira species. Int J Syst Bacteriol 37, 407415. 